\title{
Five novel Kitasatospora species from soil: Kitasatospora arboriphila sp. nov., K. gansuensis sp. nov., $K$. nipponensis sp. nov., $K$. paranensis sp. nov. and $K$. terrestris sp. nov.
}

\author{
Ingrid Groth, ${ }^{1}$ Carlos Rodríguez, ${ }^{2}$ Barbara Schütze, ${ }^{1}$ Petra Schmitz, ${ }^{3}$ \\ Eckhard Leistner ${ }^{3}$ and Michael Goodfellow ${ }^{2}$ \\ ${ }^{1}$ Hans-Knöll-Institut für Naturstoff-Forschung eV, D-07745 Jena, Germany \\ ${ }^{2}$ School of Biology, University of Newcastle, Newcastle upon Tyne NE1 7RU, UK \\ ${ }^{3}$ Rheinische Friedrich-Wilhelms-Universität, Institut für Pharmazeutische Biologie, D-53115 \\ Bonn, Germany
}

Correspondence Michael Goodfellow m.goodfellow@ncl.ac.uk

\begin{abstract}
A polyphasic study was carried out to establish the taxonomic positions of six strains isolated from diverse soil samples and provisionally assigned to the genus Kitasatospora. The isolates were found to have chemical and morphological properties consistent with their classification as Kitasatospora strains. Direct 16S rRNA gene sequence data confirmed the taxonomic position of the strains following the generation of phylogenetic trees by using three tree-making algorithms. Five of the isolates were considered to merit species status using complementary genotypic and phenotypic data. These organisms were designated Kitasatospora arboriphila sp. nov. $\left(\right.$ HKI $0189^{\top}=2291-120^{\top}=$ DSM $44785^{\top}=$ NCIMB $\left.13973^{\top}\right)$, Kitasatospora gansuensis sp. nov. $\left(H K I 0314^{\top}=2050-015^{\top}=\right.$ DSM $44786^{\top}=$ NCIMB $\left.13974^{\top}\right)$, Kitasatospora nipponensis sp. nov. $\left(\mathrm{HKI} 0315^{\top}=2148-013^{\top}=\mathrm{DSM} 44787^{\top}=\mathrm{NCIMB} 13975^{\top}\right)$, Kitasatospora paranensis sp. nov. $\left(H K I 0190^{\top}=2292-041^{\top}=\mathrm{DSM} 44788^{\top}=\mathrm{NCIMB} 13976^{\top}\right)$ and Kitasatospora terrestris sp. nov. $\left(\mathrm{HKI} 0186^{\top}=2293-012^{\top}=\mathrm{DSM} 44789^{\top}=\mathrm{NCIMB} 13977^{\top}\right)$. The remaining organism, isolate HKI 0316 (=2122-022=DSM $44790=$ NCIMB 13978), was considered to be a strain of Kitasatospora kifunensis on the basis of 16S rRNA gene sequence, DNA-DNA relatedness and phenotypic data.
\end{abstract}

The genera Kitasatospora, Streptacidiphilus and Streptomyces form the family Streptomycetaceae Waksman and Henrici 1943 emend. Kim et al. 2003. The genus Kitasatospora (formerly Kitasatosporia) was proposed by Ōmura et al. (1982) and currently includes aerobic, Gram-positive, nonmotile, chemo-organotrophic actinomycetes that form an extensively branched substrate mycelium, aerial hyphae that differentiate into long chains of spores, contain $\mathrm{N}$-acetylated muramic acid, major proportions of diphosphatidylglycerol, phosphatidylethanolamine, phosphatidylglycerol, phosphatidylinositol and phosphatidylinositol mannosides (phospholipid type 2 sensu Lechevalier et al., 1977), predominant amounts of hexahydrogenated menaquinones with nine isoprene units, fatty acids with major

Abbreviation: $A_{2} p m$, diaminopimelic acid.

The GenBank/EMBL/DDBJ accession numbers for the 16S rRNA gene sequences of strains HKI 0315 ${ }^{\top}$, HKI 0316, HKI 0189, HKI $0314^{\top}$, HKI $0186^{\top}$ and $\mathrm{HKI} 0190^{\top}$ are AY442263-AY442268, respectively. amounts of iso and anteiso components and wholeorganism hydrolysates that are typically rich in galactose, and in LL- and meso-diaminopimelic acid (meso- $\mathrm{A}_{2} \mathrm{pm}$ ). Aerial spores on solid culture and submerged spores in liquid media contain LL- $\mathrm{A}_{2} \mathrm{pm}$ whereas mycelia grown under both cultural conditions have mainly meso- $\mathrm{A}_{2} \mathrm{pm}$ (Ōmura et al., 1981, 1982; Takahashi et al., 1984; Groth et al., 2003).

The 13 species of Kitasatospora that have validly published names at the time of writing are Kitasatospora azatica (Nakagaito et al. 1993) Zhang et al. 1997, Kitasatospora cheerisanensis Chung et al. 1999, Kitasatospora cineracea Tajima et al. 2001, Kitasatospora cochleata (Nakagaito et al. 1993) Zhang et al. 1997, Kitasatospora cystarginea Kusakabe and Isono 1992, Kitasatospora griseola Takahashi et al. 1985, Kitasatospora kifunensis (Nakagaito et al. 1993) Groth et al. 2003, Kitasatospora mediocidica Labeda 1988, Kitasatospora niigatensis Tajima et al. 2001, Kitasatospora paracochleata (Nakagaito et al. 1993) Zhang et al. 1997, Kitasatospora phosalacinea Takahashi et al. 1985, 
Kitasatospora putterlickiae Groth et al. 2003 and Kitasatospora setae Ōmura et al. 1983 [species name corrected by Ōmura et al. (1985)]; K. setae is the type species of the genus. Members of these species form a distinct phyletic line in the 16S rRNA gene tree and can be delineated using a combination of genotypic and phenotypic data (Nakagaito et al., 1992a, b; Groth et al., 2003).

Six out of 18 Kitasatospora strains isolated from soil samples collected from several geographical locations during a study designed to improve the isolation and rapid differentiation of kitasatosporae from phylogenetically similar streptomycetes were the subject of a polyphasic taxonomic study. This showed that five of the six strains should be recognized as novel species. Strains HKI $0315^{\mathrm{T}}$ $\left(=2148-013^{\mathrm{T}}\right)$, HKI $0316(=2122-022)$ and HKI $0314^{\mathrm{T}}$ $\left(=2050-015^{\mathrm{T}}\right)$ were isolated from soil samples collected in Kumagura and Kyoto, Japan, and in Gansu Province, China, respectively, using PY-BHI agar (Yokota et al., 1993) and a standard dilution plate procedure; these isolates were originally misclassified as streptomycetes. Strains HKI $0190^{\mathrm{T}}\left(=2292-041^{\mathrm{T}}\right)$, HKI $0186^{\mathrm{T}}\left(=2293-012^{\mathrm{T}}\right)$ and HKI $0189^{\mathrm{T}}\left(=2291-120^{\mathrm{T}}\right)$ were isolated from rhizosphere soil of Maytenus plants in Brazil using either PY-BHI agar (strains HKI $0186^{\mathrm{T}}$ and HKI $0190^{\mathrm{T}}$ ) or yeast extract/starch agar (Kudo et al., 1993) (strain HKI 0189 ${ }^{\mathrm{T}}$ ) and a phageassisted isolation method.

The phage-assisted isolation method involved heating airdried soil $(1 \mathrm{~g})$ at $80^{\circ} \mathrm{C}$ in a dry oven for $1 \mathrm{~h}$, making a soil suspension in $10 \mathrm{ml}$ aqueous sodium pyrophosphate $(0 \cdot 2 \% \mathrm{w} / \mathrm{v})$, mixing on a rotary shaker for $30 \mathrm{~min}$, and allowing the soil particles to settle prior to decanting the supernatant, which was kept at $4{ }^{\circ} \mathrm{C}$. The soil fraction was treated with the same amount of solvent and the resultant preparation was ultrasonicated for $5 \mathrm{~min}$ at $50 \mathrm{~W}$. The second supernatant was added to the first, the combined preparation was diluted and $0 \cdot 1 \mathrm{ml}$ aliquots of the various dilutions were spread over casein mineral (Altenburger et al., 1996), humic acid (Hayakawa \& Nonomura, 1987), PY-BHI agar (Yokota et al., 1993) and yeast extract starch agar isolation plates, which were carefully overlaid with $100 \mu \mathrm{l}$ per plate of a high titre suspension (about $10^{8}-10^{9}$ plaque-forming units) of polyvalent Streptomyces phage S7 (DSM 49153) and incubated at $28^{\circ} \mathrm{C}$ for up to 4 weeks. Colonies that exhibited a Streptomyces-like morphology were transferred to oatmeal agar plates (ISP medium 3; Shirling \& Gottlieb, 1966) and incubated for further growth. These isolates were checked again for their susceptibility to Streptomyces phage S7 as described below. All S7-resistant strains were grown on organic medium 79 (Prauser et al., 1987) and oatmeal agar, which favour the growth of vegetative mycelium (contains meso- $\mathrm{A}_{2} \mathrm{pm}$ ) and spores (contain LL- $\mathrm{A}_{2} \mathrm{pm}$ ), respectively. Strains found to contain both of these isomers were studied further.

Biomass for the chemotaxonomic analyses of the six isolates and marker strains of $K$. azatica (DSM $41650^{\mathrm{T}}$ ), K. kifunensis (DSM 41654 ${ }^{\mathrm{T}}$ ), K. mediocidica $\left(\mathrm{DSM} 43929^{\mathrm{T}}\right)$,
K. phosalacinea (DSM $43860^{\mathrm{T}}$ ) and K. putterlickiae (DSM $44665^{\mathrm{T}}$ ) was prepared by cultivating them for $24-48 \mathrm{~h}$ at $28^{\circ} \mathrm{C}$ in liquid organic medium 79 and bacto-tryptic soy broth (Sigma-Aldrich). The strains were grown on ISP media 2, 3, 4 and 5 (Difco; Shirling \& Gottlieb, 1966) at $28^{\circ} \mathrm{C}$ for up to 21 days, after which cultural and morphological properties were recorded; morphological features were observed by light and electron microscopy. The dimensions of the spores were measured by using an Axioskop 2 microscope equipped with image-analysing AXIO VISION 2.05 software (both from Zero). Samples for electron microscopy were prepared from heavily sporulating cultures grown on ISP medium 3 following Shirling \& Gottlieb (1966) and observed by using a Zeiss EM 902A electron microscope at an acceleration voltage of $80 \mathrm{kV}$.

Physiological tests were carried out as described by Groth et al. (2003). Susceptibility to most of the tested antibiotics was examined by placing antibiotic discs (Difco) on organic medium 79 agar plates that were seeded with suspensions of the test strains grown in a soft agar layer for up to 2 days at $28^{\circ} \mathrm{C}$. Nalidixic acid and novobiocin were added to ISP 2 agar plates, which were then seeded with spores of the strains. Susceptibility to polyvalent Streptomyces phages was tested by dropping high-titre suspensions of phage S7 (DSM 49153) onto agar plates seeded with spores of the test strains held in a soft agar layer; the phage was propagated as described by Groth et al. (2003). Standard procedures were used to determine the isomers of $\mathrm{A}_{2} \mathrm{pm}$ in whole-organism hydrolysates (Rhuland et al., 1955; Hasegawa et al., 1983), type of muramic acid (Uchida \& Aida, 1984) and presence of mycolic acids (Minnikin et al., 1975), together with whole-organism fatty acid (MIDI system; Agilent), menaquinone (Collins et al., 1977), polar lipid (Minnikin et al., 1979; Collins \& Jones, 1980) and sugar profiles (Becker et al., 1965; Saddler et al., 1991).

16S rRNA gene sequence amplification and analysis of strains HKI $0186^{\mathrm{T}}$, HKI $0189^{\mathrm{T}}$ and HKI $0190^{\mathrm{T}}$ were carried out as described by Edwards et al. (1989), and of strains HKI $0314^{\mathrm{T}}$, HKI $0315^{\mathrm{T}}$ and HKI 0316 as described by Kim et al. (1998). The resultant sequences were aligned manually with corresponding almost complete sequences of representatives of most actinomycete genera; in each case reference sequences were retrieved from DDBJ/EMBL/GenBank. Phylogenetic analysis was carried out using the leastsquares (Fitch \& Margoliash, 1967), maximum-likelihood (Felsenstein, 1981) and neighbour-joining (Saitou \& Nei, 1987) tree-making algorithms from the PHYLIP 3.5c package (Felsenstein, 1993). Evolutionary distance matrices for the neighbour-joining method were generated according to the model of Jukes \& Cantor (1969). The stability of the resultant unrooted tree topologies were evaluated by carrying out bootstrap analyses (Felsenstein, 1985) of the neighbour-joining data based on 1000 resamplings, using the SEQBOOT and CONSENSE options from the PHYLIP 3.5c software.

DNA was extracted from the strains included in the 
DNA-DNA relatedness studies using a French pressure cell (Thermo Spectronic) and then purified by chromatography on hydroxyapatite as described by Cashion et al. (1977). DNA-DNA hybridizations were carried out in $2 \times$ SSC and DMSO $(10 \%, v / v)$ at $70{ }^{\circ} \mathrm{C}$, using modifications (Escara \& Hutton, 1980; Huß et al., 1983) of the procedure described by De Ley et al. (1970) and a model 2600 spectrophotometer equipped with a model 2527-R thermoprogrammer and plotter (Gilford Instrument Laboratories). Renaturation rates were computed using the TRANSFER.BAS program of Jahnke (1992).

Preliminary phylogenetic analysis of the almost complete 16S rRNA gene sequences of the six isolates (1368-1444 nt) placed them within the evolutionary radiation occupied by the genus Kitasatospora (data not shown). The isolates were aerobic, Gram-positive, non-motile, formed nonfragmenting, extensively branched substrate mycelia, aerial hyphae that differentiated into long chains of smoothsurfaced spores (Fig. 1) and grew well on ISP media (Table 1 ) and within the $\mathrm{pH}$ range $5 \cdot 0-9 \cdot 5$. They were also characterized by the presence of $\mathrm{N}$-acetylated muramic acid, galactose, predominant proportions of hexahydrogenated menaquinones with nine isoprene units, major amounts of diphosphatidylglycerol, phosphatidylethanolamine, phosphatidylglycerol, phosphatidylinositol and phosphatidylinositol mannosides, LL- and meso- $\mathrm{A}_{2} \mathrm{pm}$ in whole-organism hydrolysates and contained varying proportions of iso- and anteiso-branched, straight-chain and unsaturated fatty acids (Table 2) but lacked mycolic acids. The isolates were resistant to polyvalent Streptomyces phage S7. All of these properties are consistent with their classification in the genus Kitasatospora (Ōmura et al., 1982; Zhang et al., 1997). This phenotypic profile also serves to distinguish the isolates from members of the genera Streptacidiphilus and Streptomyces (Kim et al., 2003a). The isolates were sensitive to low concentrations of novobiocin $\left(5 \mu \mathrm{g} \mathrm{ml}^{-1}\right)$ and hence are unlikely to grow on the novobiocin-containing agar medium used by Tajima et al. (2001) to isolate K. cineracea and K. niigatensis strains.

It is evident from Fig. 2 that the six isolates are scattered throughout the Kitasatospora 16S rRNA gene sequence tree. The closest relationship between any of the isolates is between strain HKI 0316 and K. kifunensis NBRC $15206^{\mathrm{T}}$. This relationship is supported by all three tree-making algorithms and by a bootstrap value of $77 \%$ in the neighbour-joining analysis. The two strains share a $16 \mathrm{~S}$ rRNA gene sequence similarity of $99.6 \%$, which corresponds to $6 \mathrm{nt}$ differences over 1365 locations. However, they have a DNA-DNA relatedness of $78 \%$, a value well above the $70 \%$ cut-off point recommended for the delineation of genomic species (Wayne et al., 1987). The two strains also share key phenotypic properties, notably the ability to form short cylindrical, smooth-surfaced spores
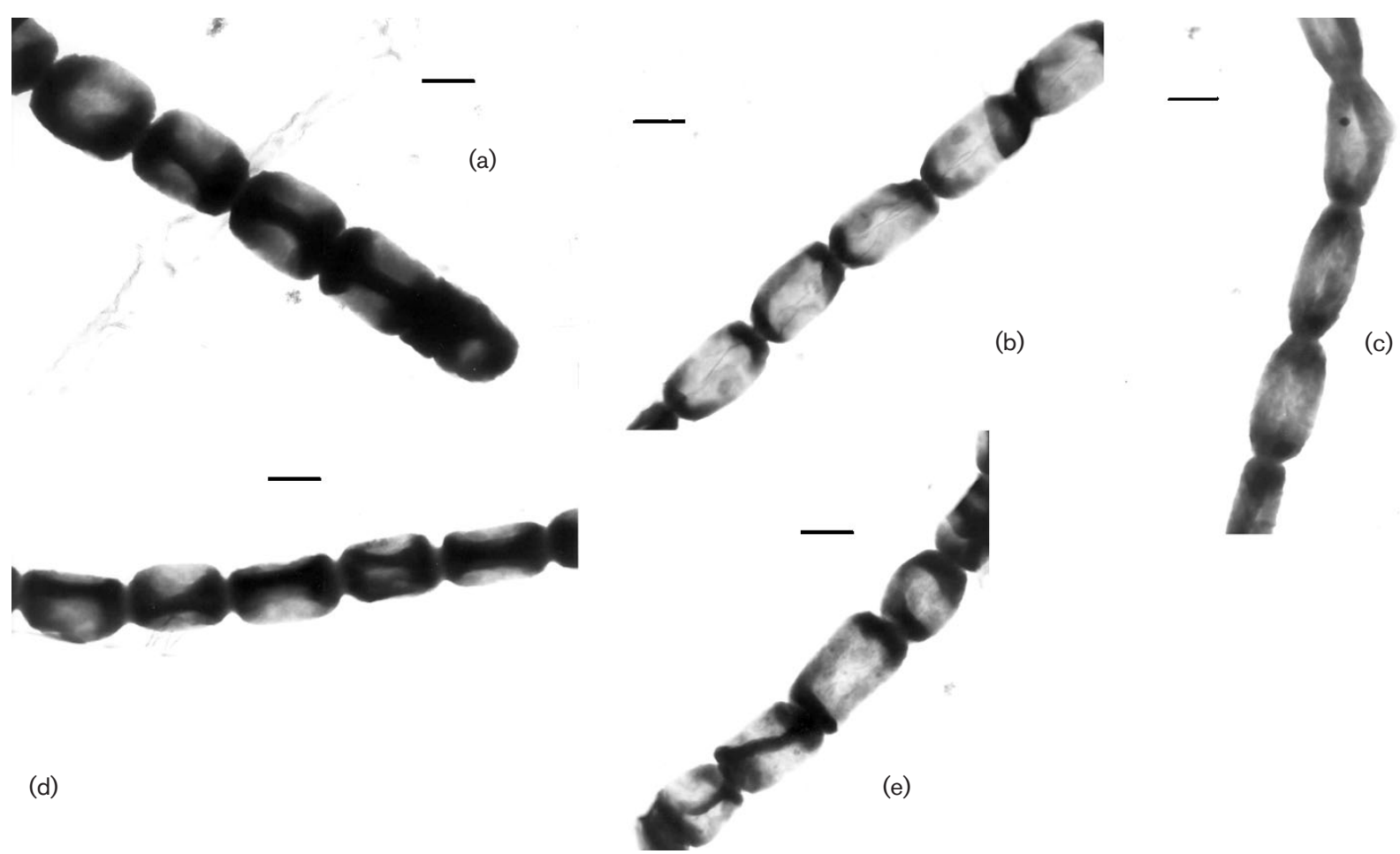

(d)

Fig. 1. Electron micrographs of spores of Kitasatospora isolates grown on ISP3 agar for 21 days at $28^{\circ} \mathrm{C}$. (a) $\mathrm{K}$. arboriphila

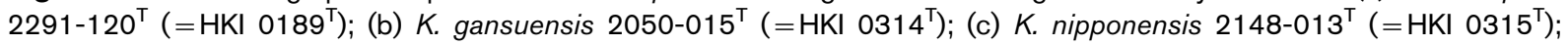

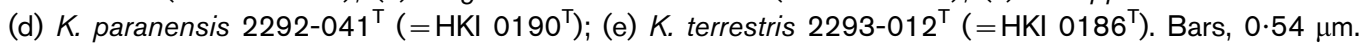


Table 1. Growth of Kitasatospora isolates on ISP media

None of the strains produced soluble pigment on ISP2, ISP4 or ISP5 media.

\begin{tabular}{|c|c|c|c|c|c|c|}
\hline Characteristic & HKI $0315^{\mathrm{T}}$ & HKI $0189^{T}$ & HKI $0316^{\mathrm{T}}$ & HKI $0314^{T}$ & HKI $0190^{T}$ & HKI $0186^{\mathrm{T}}$ \\
\hline \multicolumn{7}{|l|}{ ISP2 medium } \\
\hline Growth & Good & Good & Abundant & Good & Moderate & Abundant \\
\hline Aerial mycelium & $\begin{array}{l}\text { Absent or sparse; } \\
\text { white }\end{array}$ & White to grey & White, pale grey & White & Sparse; white & Grey \\
\hline Reverse colour & Yellowish brown & Yellowish brown & Orange, brown & Orange, brown & Yellowish brown & $\begin{array}{l}\text { Yellowish brown to } \\
\text { dark brown }\end{array}$ \\
\hline \multicolumn{7}{|l|}{ ISP3 medium } \\
\hline Growth & Abundant & Abundant & Abundant & Good & Abundant & Abundant \\
\hline Aerial mycelium & Grey & Grey to dark grey & Grey & White & Grey & Grey \\
\hline Reverse colour & $\begin{array}{l}\text { Reddish brown, } \\
\text { dark brown }\end{array}$ & $\begin{array}{l}\text { Greyish brown, dark } \\
\text { brown }\end{array}$ & Yellowish brown & $\begin{array}{l}\text { Orange-brown to } \\
\text { brown }\end{array}$ & $\begin{array}{l}\text { Yellowish brown, } \\
\text { dark brown }\end{array}$ & $\begin{array}{l}\text { Yellowish brown to } \\
\text { brown }\end{array}$ \\
\hline Soluble pigment & Purple & None & None & None & None & None \\
\hline \multicolumn{7}{|l|}{ ISP4 medium } \\
\hline Growth & Good & Good & Good & Good & Moderate & Moderate \\
\hline Aerial mycelium & $\begin{array}{l}\text { Absent or sparse; } \\
\text { white, grey }\end{array}$ & Grey to dark grey & Grey & Sparse; white, beige & $\begin{array}{l}\text { Sparse; white to } \\
\text { pale grey }\end{array}$ & Sparse; white, grey \\
\hline Reverse colour & $\begin{array}{l}\text { Yellowish brown, } \\
\text { brown }\end{array}$ & Yellowish grey, olive & Beige, brown & $\begin{array}{l}\text { Yellowish brown to } \\
\text { dark brown }\end{array}$ & Yellowish brown & $\begin{array}{l}\text { Yellowish brown, } \\
\text { greyish brown }\end{array}$ \\
\hline \multicolumn{7}{|l|}{ ISP5 medium } \\
\hline Growth & Moderate & Good & Good & Good & Moderate & Good \\
\hline Aerial mycelium & $\begin{array}{l}\text { Absent or sparse; } \\
\text { white }\end{array}$ & Grey & Grey & White & Pale grey & Sparse; grey \\
\hline Reverse colour & Reddish brown & $\begin{array}{l}\text { Yellowish grey, dark } \\
\text { greyish brown }\end{array}$ & Beige, brown & $\begin{array}{l}\text { Yellowish brown to } \\
\text { dark brown }\end{array}$ & $\begin{array}{l}\text { Yellowish brown } \\
\text { to brown }\end{array}$ & Yellowish grey \\
\hline
\end{tabular}

Table 2. Cellular fatty acid compositions (\%) of the Kitasatospora isolates and K. kifunensis DSM $41654^{\top}$

Strains: 1, HKI $0190^{\mathrm{T}}$; 2, HKI $0186^{\mathrm{T}}$; 3, HKI $0189^{\mathrm{T}}$; 4, HKI $0315^{\mathrm{T}}$; 5, HKI $0316^{\mathrm{T}}$; 6, K. kifunensis DSM $41654^{\mathrm{T}}$; 7, HKI $0314^{\mathrm{T}}$. - , Not detected.

\begin{tabular}{|c|c|c|c|c|c|c|c|}
\hline Fatty acid & 1 & 2 & 3 & 4 & 5 & 6 & 7 \\
\hline \multicolumn{8}{|l|}{ Saturated: } \\
\hline $\mathrm{C}_{14: 0}$ & $1 \cdot 0$ & $0 \cdot 6$ & $0 \cdot 4$ & $0 \cdot 4$ & $0 \cdot 7$ & $1 \cdot 4$ & $0 \cdot 8$ \\
\hline $\mathrm{C}_{15: 0}$ & $5 \cdot 0$ & $1 \cdot 1$ & $2 \cdot 1$ & $1 \cdot 2$ & $2 \cdot 1$ & $3 \cdot 7$ & $1 \cdot 4$ \\
\hline $\mathrm{C}_{16: 0}$ & $14 \cdot 1$ & $9 \cdot 3$ & $7 \cdot 4$ & $5 \cdot 9$ & $17 \cdot 0$ & $25 \cdot 3$ & $18 \cdot 6$ \\
\hline \multicolumn{8}{|l|}{ Unsaturated: } \\
\hline $\mathrm{C}_{16: 1} \omega 7 c$ & $6 \cdot 8$ & $8 \cdot 3$ & $4 \cdot 9$ & $9 \cdot 4$ & $12 \cdot 4$ & $6 \cdot 8$ & $9 \cdot 7$ \\
\hline $\mathrm{C}_{17: 1} \omega 7 c$ & $1 \cdot 7$ & $1 \cdot 0$ & $0 \cdot 5$ & $0 \cdot 6$ & $1 \cdot 6$ & $0 \cdot 7$ & $0 \cdot 5$ \\
\hline $\mathrm{C}_{18: 1} \omega 7 c$ & $0 \cdot 7$ & $2 \cdot 4$ & - & $0 \cdot 2$ & $0 \cdot 7$ & $0 \cdot 5$ & $1 \cdot 0$ \\
\hline \multicolumn{8}{|l|}{ Branched: } \\
\hline iso- $\mathrm{C}_{14: 0}$ & $4 \cdot 2$ & $2 \cdot 3$ & $2 \cdot 6$ & $4 \cdot 6$ & $0 \cdot 6$ & $0 \cdot 5$ & $1 \cdot 3$ \\
\hline iso- $\mathrm{C}_{15: 0}$ & $9 \cdot 4$ & $16 \cdot 0$ & $16 \cdot 7$ & $10 \cdot 2$ & $15 \cdot 8$ & $12 \cdot 9$ & $10 \cdot 3$ \\
\hline anteiso- $\mathrm{C}_{15: 0}$ & $16 \cdot 3$ & $10 \cdot 4$ & $11 \cdot 6$ & $8 \cdot 7$ & $12 \cdot 9$ & $16 \cdot 8$ & $21 \cdot 4$ \\
\hline iso- $\mathrm{C}_{16: 1} \mathrm{H}$ & $2 \cdot 6$ & $3 \cdot 9$ & $6 \cdot 6$ & $7 \cdot 0$ & $0 \cdot 6$ & $0 \cdot 4$ & $2 \cdot 0$ \\
\hline iso- $\mathrm{C}_{16: 0}$ & $19 \cdot 3$ & $21 \cdot 4$ & $25 \cdot 4$ & $37 \cdot 7$ & $6 \cdot 4$ & $3 \cdot 9$ & $10 \cdot 1$ \\
\hline anteiso- $\mathrm{C}_{17: 1} \mathrm{C}$ & $1 \cdot 8$ & $2 \cdot 3$ & $2 \cdot 3$ & $1 \cdot 4$ & $2 \cdot 4$ & $1 \cdot 5$ & $2 \cdot 4$ \\
\hline iso- $\mathrm{C}_{17: 0}$ & $2 \cdot 0$ & $5 \cdot 3$ & $4 \cdot 6$ & $1 \cdot 6$ & $5 \cdot 0$ & $2 \cdot 6$ & $3 \cdot 1$ \\
\hline anteiso- $\mathrm{C}_{17: 0}$ & $5 \cdot 4$ & $5 \cdot 8$ & $5 \cdot 8$ & $3 \cdot 0$ & $7 \cdot 3$ & $5 \cdot 4$ & $8 \cdot 9$ \\
\hline 9-Methyl-C $16: 0$ & $2 \cdot 0$ & $7 \cdot 2$ & $6 \cdot 4$ & $4 \cdot 2$ & $8 \cdot 3$ & $4 \cdot 5$ & $4 \cdot 3$ \\
\hline $\mathrm{C}_{17: 0}$ cyclo & $3 \cdot 6$ & $0 \cdot 7$ & $1 \cdot 2$ & $1 \cdot 9$ & $3 \cdot 9$ & $9 \cdot 4$ & $2 \cdot 2$ \\
\hline
\end{tabular}

in straight to spiral spore chains (rectiflexibiles to spirales), to produce melanin pigments on tyrosine agar, to hydrolyse starch, to produce $\beta$-galactosidase, $\alpha$-glucosidase, $\alpha$-mannosidase and naphthol-AS-BI phosphohydrolase, to use $(+)$-D-mannitol and $(+)$-D-sucrose as sole carbon sources and to grow in the presence of $\mathrm{NaCl}(2 \cdot 5 \%, \mathrm{w} / \mathrm{v})$, lincomycin hydrochloride $(2 \mu \mathrm{g})$, penicillin $\mathrm{G}(10 \mathrm{IU})$ and polymyxin B (300 IU). In contrast, neither of the organisms is able to liquefy gelatin, peptonize milk, reduce nitrate, grow on $(+)$-D-raffinose or $(+)$-L-rhamnose as sole carbon sources or to produce $\beta$-glucosidase or $N$-acetyl- $\beta$ glucosamidase. The two strains have a fatty acid profile rich in $\mathrm{C}_{16: 0}$, anteiso- $\mathrm{C}_{15: 0}$ and iso- $\mathrm{C}_{15: 0}$ components. These data are consistent with the assignment of isolate HKI 0316 (=2122-022) to K. kifunensis (Nakagaito et al. 1993) Groth et al. 2003.

Isolates HKI $0190^{\mathrm{T}}$ and $\mathrm{HKI} 0186^{\mathrm{T}}$ are closely related to K. cystarginea (Fig. 2); they share $16 \mathrm{~S}$ rRNA gene sequence similarities with this organism of 98.5 and $99.0 \%$, respectively, values equivalent to 15 and $14 \mathrm{nt}$ differences at 1430 locations. However, the two isolates are more closely related to one another, having a $16 \mathrm{~S}$ rRNA gene sequence similarity of $99.2 \%$, which corresponds to 12 nt differences at 1444 sites, but clearly belong to distinct genomic species as they share a DNA-DNA relatedness of $40 \cdot 1 \%$. It is also evident from Tables 2 and 3 that these organisms 


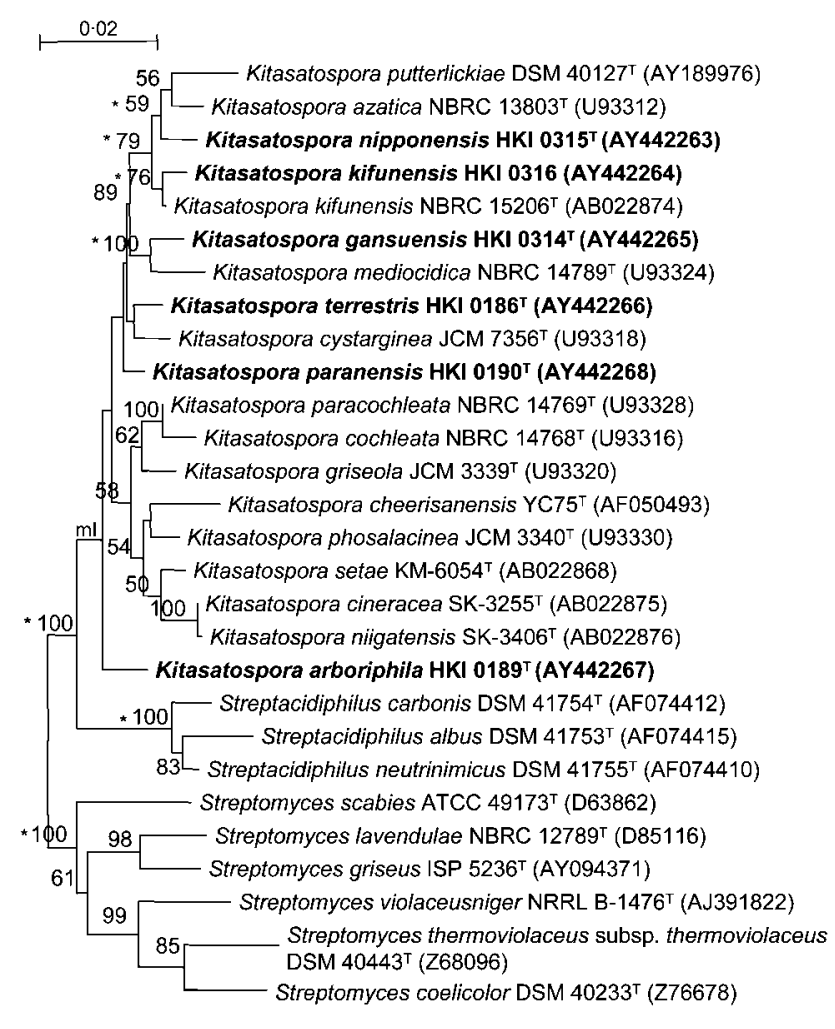

Fig. 2. Unrooted neighbour-joining tree (Saitou \& Nei, 1987) based on nearly complete $16 \mathrm{~S}$ rRNA gene sequences showing the position of the six isolates in the Kitasatospora tree. Asterisks indicate branches that were also recovered using the least-squares (Fitch \& Margoliash, 1967), maximum-likelihood (Felsenstein, 1981) and maximum-parsimony (Felsenstein, 1993) algorithms; ' $m l$ ' denotes branches that were formed using the maximum-likelihood tree-making method. Numbers at nodes are bootstrap values (\%) based on 1000 resampled datasets; only values $>50 \%$ are given. Bar, 0.02 nucleotide substitutions per nucleotide position.

can be distinguished using a broad range of phenotypic properties. These data indicate that isolates HKI $0190^{\mathrm{T}}$ and HKI $0186^{\mathrm{T}}$ form novel centres of taxonomic variation in the genus Kitasatospora for which the names Kitasatospora paranensis sp. nov. and Kitasatospora terrestris sp. nov. are proposed.

Isolate HKI $0315^{\mathrm{T}}$ was most closely related to the type strains of K. azatica and K. kifunensis; it showed a $16 \mathrm{~S}$ rRNA gene sequence similarity to these organisms of $99 \cdot 1 \%$ and $99 \cdot 2 \%$, values that correspond to 13 and $11 \mathrm{nt}$ differences at 1387 and 1377 locations, respectively. DNA-DNA relatedness studies were not carried out between this isolate and the type strains of $K$. azatica and $K$. kifunensis as it has been established that kitasatosporae with similar 16S rRNA gene sequence similarities show relatedness values well below the cut-off point recommended for the delineation of genomic species (Wayne et al., 1987). This is exemplified in the present study by isolates HKI $0190^{\mathrm{T}}$ and HKI $0186^{\mathrm{T}}$. It is evident from Tables 2 and 3 that isolate HKI $0315^{\mathrm{T}}$ can be distinguished from K. kifunensis DSM $41654^{\mathrm{T}}$ using several phenotypic properties. It is clear that isolate HKI $0315^{\mathrm{T}}$ merits species status in the genus Kitasatospora; the name proposed for this novel taxon is Kitasatospora nipponensis sp. nov.

The relatively close phylogenetic relationship found between isolate HKI $0314^{\mathrm{T}}$ and $K$. mediocidica NBRC $14789^{\mathrm{T}}$ is supported by the results from all of the treemaking algorithms and by a bootstrap value of $90 \%$ in the neighbour-joining analysis (Fig. 2). The two organisms share a 16S rRNA gene sequence similarity of $98 \cdot 7 \%$, a value equivalent to $19 \mathrm{nt}$ differences at 1429 sites. The two strains can be separated readily using a combination of phenotypic properties (Table 3). It is proposed that isolate HKI $0314^{\mathrm{T}}$ be recognized as a novel Kitasatospora species, for which the name Kitasatospora gansuensis sp. nov. is proposed.

The final isolate, strain HKI $0189^{\mathrm{T}}$, forms a distinct phyletic line at the foot of the 16S rRNA Kitasatospora gene sequence tree (Fig. 2). This organism is most closely related to $K$. phosalacinea; the two organisms share a $16 \mathrm{~S}$ rRNA gene sequence similarity of $98 \cdot 7 \%$, a value corresponding to $19 \mathrm{nt}$ differences at 1423 locations. However, strain HKI $0189^{\mathrm{T}}$ can be distinguished from K. phosalacinea using several phenotypic properties (Table 3 ). It is apparent from these data that isolate HKI $0189^{\mathrm{T}}$ forms a novel centre of taxonomic variation in the genus Kitasatospora, for which the name Kitasatospora arboriphila sp. nov. is proposed.

\section{Description of Kitasatospora arboriphila sp. nov.}

Kitasatospora arboriphila (ar.bo.ri.phi'la. L. n. arbor a tree; Gr. adj. philos loving, N.L. fem. adj. arboriphila tree loving).

Aerobic, Gram-positive, non-acid-fast actinomycete that produces a yellowish brown to dark brown or olive substrate mycelium and a grey to dark grey aerial spore mass on glycerol/asparagine, inorganic salts/starch, oatmeal and yeast extract/malt extract agars. Soluble pigments are not formed, but melanoid pigments are produced on peptone/ yeast extract/iron and tyrosine agars. Spore chains are long, straight to spiral with hooks and loops with 20 or more cylindrical, smooth-surfaced spores $(1 \cdot 1-1 \cdot 7 \times 1 \cdot 3-2 \cdot 4 \mu \mathrm{m})$ per chain (Fig. 1a). Submerged spores are formed sparsely in liquid culture. Temperature range for growth is $15-40{ }^{\circ} \mathrm{C}$ (optimum $28-32^{\circ} \mathrm{C}$ ); growth does not occur at $10^{\circ} \mathrm{C}$ or above $40^{\circ} \mathrm{C}$. $\mathrm{pH}$ range for good growth is $\mathrm{pH} 5 \cdot 0-8 \cdot 0$; growth does not occur at either $\mathrm{pH} 4.5$ or $\mathrm{pH} 9 \cdot 0$. Additional phenotypic properties are given in Table 3. The cell wall contains meso- and LL- $\mathrm{A}_{2} \mathrm{pm}$; the muramic acid moiety is $\mathrm{N}$-acetylated. Whole-organism hydrolysates contain galactose, mannose, glucose and ribose. The major polar lipids are phosphatidylethanolamine, diphosphatidylglycerol, phosphatidylglycerol, phosphatidylinositol and phosphatidylinositol mannosides. The predominant fatty 
Table 3. Phenotypic properties that separate the novel isolates from one another and from representatives of closely related Kitasatospora species

Taxa: 1, K. nipponensis sp. nov. HKI $0315^{\mathrm{T}}$; 2, K. azatica DSM 41650 ; 3, K. putterlickiae DSM 44665 $5^{\mathrm{T}}$; 4, K. arboriphila sp. nov. HKI $0189^{\mathrm{T}}$; 5, K. phosalacinea DSM $43860^{\mathrm{T}}$; 6, K. kifunensis HKI 0316; 7, K. kifunensis DSM 41654 ${ }^{\mathrm{T}}$; 8, K. gansuensis sp. nov. HKI 0314 ${ }^{\mathrm{T}}$; 9 , K. mediocidica DSM 43929 $; 10$, K. paranensis sp. nov. HKI $0190^{\mathrm{T}}$; 11, K. terrestris sp. nov. HKI $0186^{\mathrm{T}} ; 12$, K. cystarginea DSM $41680^{\mathrm{T}}$. + , Positive; - , negative; $(+)$, weakly positive; \pm , doubtful; ND, not determined. For the following properties, tests for which strain DSM $41680^{\mathrm{T}}$ was not tested are indicated by ' $a$ '. Spores of all of the tested strains are cylindrical with a smooth surface. All strains were positive for the production of $\mathrm{H}_{2} \mathrm{~S}^{a}$, growth on $(+)$-D-glucose, and produced acid phosphatase, alkaline phosphatase, esterase (C4), esterase lipase (C8) and leucine arylamidase (API ZYM tests). Good growth occurred at temperatures of $15-32{ }^{\circ} \mathrm{C}$ and $\mathrm{pH} 5 \cdot 0-7 \cdot 0$. All strains were sensitive to chloramphenicol $(30 \mu \mathrm{g})^{a}$, ciprofloxacin $(5 \mu \mathrm{g})^{a}$, imipenem $(10 \mu \mathrm{g})^{a}$, kanamycin sulphate $(30 \mu \mathrm{g})^{a}$, nalidixic acid $\left(50 \mu \mathrm{g} \mathrm{ml}{ }^{-1} \text { agar }\right)^{a}$, oxytetracycline $(30 \mu \mathrm{g})^{a}$, rifampicin $(30 \mu \mathrm{g})^{a}$, streptomycin sulphate $(10 \mu \mathrm{g})^{a}$ and vancomycin $(30 \mu \mathrm{g})^{a}$. They did not use cellulose ${ }^{a}$ as a sole carbon source; did not produce $\alpha$-chymotrypsin, cystine arylamidase, $\alpha$-galactosidase, $\beta$-glucuronidase, $\alpha$-fucosidase, lipase (C14), trypsin or valine arylamidase (API ZYM tests) and did not grow in the presence of $\mathrm{NaCl}\left(4 \%\right.$, w/v) or at $42{ }^{\circ} \mathrm{C}$ and $\mathrm{pH} 4 \cdot 0$ or $\mathrm{pH} 10$.

\begin{tabular}{|c|c|c|c|c|c|c|c|c|c|c|c|c|}
\hline Test & 1 & 2 & 3 & 4 & 5 & 6 & 7 & 8 & 9 & 10 & 11 & 12 \\
\hline Spore chain morphology* & RF, RA, S & RF & $\mathrm{RF}$ & $\mathrm{RF}, \mathrm{RA}, \mathrm{S}$ & $\mathrm{RF}$ & RF, $\mathrm{S}$ & $\mathrm{RF}, \mathrm{S}$ & $\mathrm{RF}$ & RF, RA & $\mathrm{RF}$ & $\mathrm{RF}, \mathrm{RA}, \mathrm{S}$ & $s \dagger$ \\
\hline Formation of melanoid pigment & - & - & + & + & - & + & + & + & + & + & + & $-\dagger$ \\
\hline Degradation of casein & + & + & + & + & + & - & + & + & - & + & + & ND \\
\hline Liquefaction of gelatin & + & + & + & + & + & - & - & + & - & + & + & $-\dagger$ \\
\hline Hydrolysis of potato starch & + & + & - & + & + & + & + & + & + & + & + & $+\dagger$ \\
\hline Peptonization of milk & + & + & + & + & + & - & - & + & - & + & + & $+\dagger$ \\
\hline Nitrate reduction & - & + & + & + & + & - & - & + & - & + & + & $-\dagger$ \\
\hline \multicolumn{13}{|l|}{ Growth on sole carbon sources: } \\
\hline$(+)$-L-Arabinose & - & + & - & + & $+\ddagger$ & - & + & + & + & + & + & $\pm \dagger$ \\
\hline$(+)$-D-Fructose & $(+)$ & + & $(+)$ & + & $+\ddagger$ & + & - & + & + & - & + & $\pm \dagger$ \\
\hline i-Inositol & - & - & - & - & $-\ddagger$ & - & - & - & - & - & - & $+\dagger$ \\
\hline$(+)$-D-Mannitol & - & - & - & - & $-\ddagger$ & + & + & - & - & - & - & $-\dagger$ \\
\hline$(+)$-D-Raffinose & - & - & - & + & $+\ddagger$ & - & - & - & - & - & + & $-\dagger$ \\
\hline$(+)$-L-Rhamnose & - & - & - & - & $+\ddagger$ & - & - & - & - & + & $(+)$ & $-\dagger$ \\
\hline$(-)$-D-Sucrose & $(+)$ & + & $(+)$ & - & $+末$ & + & + & + & + & - & $(+)$ & $-\dagger$ \\
\hline$(+)$-D-Xylose & - & + & - & + & $+末$ & - & + & + & + & + & + & $-\dagger$ \\
\hline \multicolumn{13}{|l|}{ Enzyme assay (API ZYM): } \\
\hline$N$-Acetyl- $\beta$-glucosamidase & + & - & - & - & - & - & - & $(+)$ & - & - & - & - \\
\hline$\beta$-Galactosidase & + & + & + & $(+)$ & + & + & + & + & - & + & + & + \\
\hline$\alpha$-Glucosidase & - & $(+)$ & - & + & + & $(+)$ & + & + & - & + & $(+)$ & + \\
\hline$\beta$-Glucosidase & - & - & + & - & - & - & - & + & - & - & - & - \\
\hline$\alpha$-Mannosidase & - & - & - & - & - & + & $(+)$ & - & - & - & - & - \\
\hline Naphthol-AS-BI-phosphohydrolase & + & + & - & + & + & + & + & + & + & + & + & + \\
\hline \multicolumn{13}{|l|}{ Temperature for growth: } \\
\hline $6^{\circ} \mathrm{C}$ & - & - & - & - & - & - & - & $(+)$ & $(+)$ & - & - & $-\dagger$ \\
\hline $10^{\circ} \mathrm{C}$ & + & $(+)$ & $(+)$ & - & + & + & $(+)$ & + & + & $(+)$ & - & $-\dagger$ \\
\hline $35^{\circ} \mathrm{C}$ & $(+)$ & $(+)$ & + & + & + & + & - & - & - & + & + & $+\dagger$ \\
\hline $37^{\circ} \mathrm{C}$ & - & - & + & + & + & + & - & - & - & + & + & $+\dagger$ \\
\hline $40{ }^{\circ} \mathrm{C}$ & - & - & - & $(+)$ & + & - & - & - & - & - & + & $+\dagger$ \\
\hline $42^{\circ} \mathrm{C}$ & - & - & - & - & $+\ddagger$ & - & - & - & - & - & - & $-\dagger$ \\
\hline \multicolumn{13}{|l|}{ Growth in the presence of $\mathrm{NaCl}(\%)$ : } \\
\hline $2 \cdot 0$ & + & - & + & + & + & + & + & + & + & + & + & + \\
\hline $2 \cdot 5$ & $(+)$ & - & + & - & + & + & + & + & + & + & + & + \\
\hline $3 \cdot 0$ & - & - & + & - & - & + & - & - & - & + & $(+)$ & - \\
\hline $3 \cdot 5$ & - & - & + & - & - & + & - & - & - & + & - & - \\
\hline \multicolumn{13}{|l|}{ Growth at $\mathrm{pH}$ : } \\
\hline $8 \cdot 0$ & + & + & + & + & + & + & + & + & - & + & + & + \\
\hline $9 \cdot 0$ & - & - & + & - & + & - & + & + & - & + & + & + \\
\hline $9 \cdot 5$ & - & - & + & - & + & - & - & + & - & - & - & - \\
\hline \multicolumn{13}{|l|}{ Antibiotic susceptibility: } \\
\hline Ampicillin $(10 \mu \mathrm{g})$ & - & + & + & - & + & - & $(+)$ & $(+)$ & - & $(+)$ & - & ND \\
\hline
\end{tabular}


Table 3. cont.

\begin{tabular}{|lcccccccccccc|}
\hline Test & $\mathbf{1}$ & $\mathbf{2}$ & $\mathbf{3}$ & $\mathbf{4}$ & $\mathbf{5}$ & $\mathbf{6}$ & $\mathbf{7}$ & $\mathbf{8}$ & $\mathbf{9}$ & $\mathbf{1 0}$ & $\mathbf{1 1}$ & $\mathbf{1 2}$ \\
\hline Lincomycin hydrochloride $(2 \mu \mathrm{g})$ & - & - & - & - & - & - & - & - & $(+)$ & $(+)$ & - & $\mathrm{ND}$ \\
Methicillin $(5 \mu \mathrm{g})$ & $(+)$ & + & $(+)$ & - & - & - & $(+)$ & - & - & $(+)$ & - & $\mathrm{ND}$ \\
Norfloxacin $(10 \mu \mathrm{g})$ & - & $(+)$ & - & - & - & + & - & - & $(+)$ & - & $(+)$ & $\mathrm{ND}$ \\
Novobiocin $\left(5 \mu \mathrm{g} \mathrm{ml}{ }^{-1}\right)$ & + & + & + & + & - & + & + & + & + & + & + & $\mathrm{ND}$ \\
Penicillin G $(10 \mathrm{IU})$ & - & + & + & - & + & - & - & - & - & - & - & $\mathrm{ND}$ \\
Polymyxin B $(300 \mathrm{IU})$ & $(+)$ & + & $(+)$ & + & $(+)$ & - & - & - & $(+)$ & + & + & $\mathrm{ND}$ \\
Sulfonamide $(200 \mu \mathrm{g})$ & $(+)$ & + & - & - & - & - & $(+)$ & + & - & $(+)$ & - & $\mathrm{ND}$ \\
\end{tabular}

${ }^{\star} \mathrm{RF}$, Rectiflexibiles; RA, retinaculiaperti; S, spirales.

$\dagger$ Data from Kusakabe \& Isono (1988).

$\ddagger$ Data from Takahashi et al. (1984).

acids are iso- $\mathrm{C}_{16: 0}(25 \%)$, iso- $\mathrm{C}_{15: 0}(17 \%)$ and anteiso$\mathrm{C}_{15: 0}(12 \%)$; mycolic acids are absent. The major menaquinones are MK-9( $\left.\mathrm{H}_{6}\right)(49 \%)$ and MK-9 $\left(\mathrm{H}_{8}\right)(28 \%)$.

The type and only strain is HKI $0189^{\mathrm{T}}\left(=2291-120^{\mathrm{T}}=\right.$ DSM $44785^{\mathrm{T}}=$ NCIMB $13973^{\mathrm{T}}$ ), which was isolated from a soil sample collected from the roots of the tree Maytenus aquifolia in Ribeirao Preto, Brazil.

\section{Description of Kitasatospora gansuensis sp. nov.}

Kitasatospora gansuensis (gan.su.en'sis. N.L. fem. adj. gansuensis pertaining to Gansu, a province in China, the origin of the soil from which the type strain was isolated).

Aerobic, Gram-positive, non-acid-fast actinomycete that produces a yellowish- or orange-brown to dark-brown substrate mycelium and a white to beige aerial spore mass on glycerol/asparagine, inorganic salts/starch, oatmeal and yeast extract/malt extract agars; soluble pigments are not formed on these media but melanoid pigments are produced on peptone/yeast extract/iron and tyrosine agars. Spore chains are long, straight to flexuous, with 20 or more cylindrical, smooth-surfaced spores $(0 \cdot 8-1 \cdot 3 \times 1 \cdot 6$ $3.0 \mu \mathrm{m}$ ) per chain (Fig. 1b). Submerged spores and irregular fragments are formed in liquid culture. Temperature range for growth is $6-32{ }^{\circ} \mathrm{C}$ (optimum $25-28^{\circ} \mathrm{C}$ ); growth does not occur below $6^{\circ} \mathrm{C}$ or at $35^{\circ} \mathrm{C}$. $\mathrm{pH}$ range for good growth is $\mathrm{pH} 5 \cdot 0-9 \cdot 5$; growth does not occur at $\mathrm{pH} 4 \cdot 5$ or above $\mathrm{pH} 9 \cdot 5$. Additional phenotypic properties are given in Table 3. The cell wall contains mesoand LL- $\mathrm{A}_{2} \mathrm{pm}$; the muramic acid moiety is $\mathrm{N}$-acetylated and whole-organism hydrolysates contain galactose, ribose, mannose and rhamnose. The polar lipids are phosphatidylethanolamine, diphosphatidylglycerol, phosphatidylglycerol, phosphatidylinositol, phosphatidylinositol mannosides and an unknown glycolipid. The predominant fatty acids are anteiso- $\mathrm{C}_{15: 0}(21 \%), \mathrm{C}_{16: 0}(19 \%)$, iso- $\mathrm{C}_{15: 0}$ $(10 \%)$ and iso- $\mathrm{C}_{16: 0}(10 \%)$; mycolic acids are absent. The major menaquinone is MK- $9\left(\mathrm{H}_{6}\right)(75 \%)$.
The type and only strain is HKI $0314^{\mathrm{T}}\left(=2050-015^{\mathrm{T}}=\right.$ DSM $44786^{\mathrm{T}}=$ NCIMB $13974^{\mathrm{T}}$ ), which was isolated from a sample of forest soil collected in the Lianhua Shan Reservation, Gansu Province, China.

\section{Description of Kitasatospora nipponensis sp. nov.}

Kitasatospora nipponensis (nip.pon.en'sis. N.L. fem. adj. nipponensis pertaining to Nippon, the native name for Japan, the origin of the soil from which the type strain was isolated).

Aerobic, Gram-positive, non-acid-fast actinomycete that produces a yellowish- or reddish-brown substrate mycelium and a grey aerial spore mass on glycerol/asparagine, inorganic salts/starch, oatmeal and yeast extract/malt extract agars. A purple soluble pigment is formed on oatmeal agar, but melanoid pigments are not produced on peptone/yeast extract/iron and tyrosine agars. Spore chains are open spirals, long straight loops and hooks with 20 or more cylindrical, smooth-surfaced spores $(1 \cdot 1-1 \cdot 6 \times 1 \cdot 2-2 \cdot 3 \mu \mathrm{m})$ per chain (Fig. 1c). Submerged spores are formed in liquid culture. Temperature range for growth is $10-32{ }^{\circ} \mathrm{C}$ (optimum $25-28^{\circ} \mathrm{C}$ ); growth does not occur at $6{ }^{\circ} \mathrm{C}$ or at $37^{\circ} \mathrm{C}$. $\mathrm{pH}$ range for good growth is $\mathrm{pH} 5 \cdot 0-8 \cdot 0$; growth does not occur at $\mathrm{pH} 4 \cdot 5$ or above $\mathrm{pH} 8 \cdot 5$. Additional phenotypic properties are given in Table 3. The cell wall contains mesoand LL- $\mathrm{A}_{2} \mathrm{pm}$; the muramic acid moiety is $\mathrm{N}$-acetylated and whole-organism hydrolysates contain galactose, mannose, ribose and glucose. The major polar lipids are phosphatidylethanolamine, diphosphatidylglycerol, phosphatidylglycerol, phosphatidylinositol, phosphatidylinositol mannosides and an unknown phospholipid. The predominant fatty acids are iso- $\mathrm{C}_{16: 0}(38 \%)$ and iso- $\mathrm{C}_{15: 0}$ $(10 \%)$; mycolic acids are absent. The major menaquinone is MK-9( $\left.\mathrm{H}_{6}\right)(74 \%)$.

The type and only strain is HKI $0315^{\mathrm{T}}\left(=2148-013^{\mathrm{T}}=\mathrm{DSM}\right.$ $44787^{\mathrm{T}}=$ NCIMB $\left.13975^{\mathrm{T}}\right)$, which was isolated from a soil sample collected at Kumagura, Japan. 


\section{Description of Kitasatospora paranensis sp. nov.}

Kitasatospora paranensis (pa.ra.nen'sis. N.L. fem. adj. paranensis pertaining to Parana, a state of Brazil, the origin of the soil from which the type strain was isolated).

Aerobic, Gram-positive, non-acid-fast actinomycete that produces a yellowish-brown to dark-brown substrate mycelium and a grey aerial spore mass on glycerolasparagine, inorganic salts/starch, oatmeal and yeast extract/malt extract agars. Soluble pigments are not formed, but melanoid pigments are produced on peptone/yeast extract/iron and tyrosine agars. Spore chains are long straight to flexuous with 20 or more cylindrical, smooth-surfaced spores $(1 \cdot 1-1 \cdot 4 \times 1 \cdot 2-2 \cdot 1 \mu \mathrm{m})$ per chain (Fig. 1d). Submerged spores are rarely formed in liquid culture. Temperature range for growth is $10-37^{\circ} \mathrm{C}$ (optimum $25-28^{\circ} \mathrm{C}$ ); growth does not occur at $6{ }^{\circ} \mathrm{C}$ or at $40^{\circ} \mathrm{C}$. $\mathrm{pH}$ range for good growth is $\mathrm{pH} 5 \cdot 0-9 \cdot 0$; growth does not occur at either $\mathrm{pH} 4 \cdot 0$ or $\mathrm{pH} 9 \cdot 5$. Additional phenotypic properties are given in Table 3 . The cell wall contains both meso- and LL- $\mathrm{A}_{2} \mathrm{pm}$; the muramic acid moiety is $\mathrm{N}$-acetylated and whole-organism hydrolysates contain galactose, mannose and glucose. The polar lipids are phosphatidylethanolamine, diphosphatidylglycerol, phosphatidylglycerol, phosphatidylinositol mannosides, phosphatidylserine and an unknown phospholipid. The predominant fatty acids are iso- $\mathrm{C}_{16: 0}(19 \%)$, anteiso- $\mathrm{C}_{15: 0}$ $(16 \%)$ and $\mathrm{C}_{16: 0}(14 \%)$; mycolic acids are absent. The major menaquinone is $\mathrm{MK}-9\left(\mathrm{H}_{6}\right)(53 \%)$ with minor components MK-9 $\left(\mathrm{H}_{4}\right)(22 \%)$ and MK-9 $\left(\mathrm{H}_{2}\right)(14 \%)$.

The type and only strain is HKI $0190^{\mathrm{T}}\left(=2292-041^{\mathrm{T}}=\mathrm{DSM}\right.$ $44788^{\mathrm{T}}=$ NCIMB $13976^{\mathrm{T}}$ ), which was isolated from rhizosphere soil of Maytenus ilicifolia, Contenda, Parana State, Brazil.

\section{Description of Kitasatospora terrestris sp. nov.}

Kitasatospora terrestris (ter.res'tris. L. fem. adj. terrestris of the earth, terrestrial).

Aerobic, Gram-positive, non-acid-fast actinomycete that produces a yellowish-brown to dark-brown or greyishbrown substrate mycelium and a grey aerial spore mass on glycerol/asparagine, inorganic salts/starch, oatmeal and yeast extract/malt extract agars. Soluble pigments are not formed. The formation of melanoid pigments is weak on peptone/yeast extract/iron and tyrosine agars. Spore chains are straight, hooked and spiral with 20 or more cylindrical, smooth-surfaced spores $(1 \cdot 1-1.5 \times 1 \cdot 3-2 \cdot 8 \mu \mathrm{m})$ per chain (Fig. 1e). Submerged spores are formed in liquid culture. Temperature range for growth is $15-40{ }^{\circ} \mathrm{C}$ (optimum $28-32{ }^{\circ} \mathrm{C}$ ); growth does not occur at $10{ }^{\circ} \mathrm{C}$ or at $42{ }^{\circ} \mathrm{C}$. pH range for good growth is $\mathrm{pH} 5 \cdot 0-9 \cdot 0$; growth does not occur at $\mathrm{pH} 4 \cdot 5$ or at $\mathrm{pH} 9 \cdot 5$. Additional phenotypic properties are shown in Table 3 . The cell wall contains meso- and LL- $\mathrm{A}_{2} \mathrm{pm}$; the muramic acid moiety is $\mathrm{N}$-acetylated and whole-organism hydrolysates contain galactose, mannose and glucose. The polar lipids are phosphatidylethanolamine, diphosphatidylglycerol, phosphatidylglycerol (traces), phosphatidylinositol, phosphatidylinositol mannosides, phosphatidylserine and an unknown glycolipid. The predominant fatty acids are iso$\mathrm{C}_{16: 0}(21 \%)$, iso- $\mathrm{C}_{15: 0}(16 \%)$ and anteiso- $\mathrm{C}_{15: 0}(10 \%)$; mycolic acids are absent. The major menaquinone is MK-9 $\left(\mathrm{H}_{6}\right)(76 \%)$.

The type and only strain is HKI $0186^{\mathrm{T}}\left(=2293-012^{\mathrm{T}}=\mathrm{DSM}\right.$ $44789^{\mathrm{T}}=$ NCIMB $13977^{\mathrm{T}}$ ), which was isolated from a soil sample of the roots of Maytenus aquifolia, Ribeirao Preto, Brazil.

\section{Acknowledgements}

We are grateful to Dr W. Richter (Friedrich Schiller University) for providing electron micrographs of the spores and to R. Schön, C. Schult, C. Weigel and S. Lohmann for excellent technical assistance. C.R. was supported by a studentship from the Ecuadorian FUNDACYT (Foundation for Science and Technology) and by an Overseas Research Scholarship Award. We acknowledge support by grants from the Deutsche Forschungsgemeinschaft (Le260/15-1 and/ 15-2) and Heinrich Hertz Stiftung (to E. L.). M. G. is also grateful for support from the European Commission (grant QLK3-CT-200101783). We are also indebted to P. Schumann from the identification service of the DSMZ Braunschweig for the DNA-DNA relatedness studies.

\section{References}

Altenburger, P., Kämpfer, P., Makristathis, A., Lubitz, W. \& Busse, H. J. (1996). Classification of bacteria isolated from a medieval wall painting. J Biotechnol 47, 39-52.

Becker, B., Lechevalier, M. P. \& Lechevalier, H. A. (1965). Chemical composition of cell-wall preparations from strains of various formgenera of aerobic actinomycetes. Appl Microbiol 13, 236-243.

Cashion, P., Holder-Franklin, M. A., McCully, J. \& Franklin, M. (1977). A rapid method for the base ratio determination of bacterial DNA. Anal Biochem 81, 461-466.

Chung, Y. R., Sung, K. C., Mo, H. K., Son, D. Y., Nam, J. S., Chun, J. \& Bae, K. S. (1999). Kitasatospora cheerisanensis sp. nov., a new species of the genus Kitasatospora that produces an antifungal agent. Int J Syst Bacteriol 49, 753-758.

Collins, M. D. \& Jones, D. (1980). Lipids in the classification and identification of coryneform bacteria containing peptidoglycans based on 2,4-diaminobutyric acid. J Appl Bacteriol 48, 459-470.

Collins, M. D., Pirouz, T., Goodfellow, M. \& Minnikin, D. E. (1977). Distribution of menaquinones in actinomycetes and corynebacteria. J Gen Microbiol 100, 221-230.

De Ley, J., Cattoir, H. \& Reynaerts, A. (1970). The quantitative measurement of DNA hybridization from renaturation rates. Eur J Biochem 12, 133-142.

Edwards, U., Rogall, T., Blocker, H., Emde, M. \& Böttger, E. C. (1989). Isolation and direct complete nucleotide determination of entire genes. Characterization of a gene coding for $16 \mathrm{~S}$ ribosomal RNA. Nucleic Acids Res 17, 7843-7853.

Escara, J. F. \& Hutton, J. R. (1980). Thermal stability and renaturation of DNA in dimethyl sulfoxide solutions: acceleration of the renaturation rate. Biopolymers 19, 1315-1327.

Felsenstein, J. (1981). Evolutionary trees from DNA sequences: a maximum likelihood approach. J Mol Evol 17, 368-376. 
Felsenstein, J. (1985). Confidence limits on phylogenies, an approach using the bootstrap. Evolution 39, 783-791.

Felsenstein, J. (1993). PHYLIP (Phylogeny Inference Package), version 3.5c. Distributed by the author. Department of Genetics, University of Washington, Seattle, USA.

Fitch, W. M. \& Margoliash, E. (1967). Construction of phylogenetic trees. Science 155, 279-284.

Groth, I., Schütze, B., Boettcher, T., Pullen, C. B., Rodriguez, C., Leistner, E. \& Goodfellow, M. (2003). Kitasatospora putterlickiae sp. nov., isolated from rhizosphere soil, transfer of Streptomyces kifunensis to the genus Kitasatospora as Kitasatospora kifunensis comb. nov., and emended description of Streptomyces aureofaciens Duggar 1948. Int J Syst Evol Microbiol 53, 2033-2040.

Hasegawa, T., Takizawa, M. \& Tanida, S. (1983). A rapid analysis for chemical grouping of aerobic actinomycetes. J Gen Appl Microbiol 329, 1319-1322.

Hayakawa, M. \& Nonomura, H. (1987). Humic acid-vitamin agar, a new medium for the selective isolation of soil actinomycetes. J Ferment Technol 65, 501-509.

Huß, V. A. R., Festl, H. \& Schleifer, K. H. (1983). Studies on the spectrophotometric determination of DNA hybridization from renaturation rates. Syst Appl Microbiol 4, 184-192.

Jahnke, K. D. (1992). Basic computer program for evaluation of spectroscopic DNA renaturation data from GILFORD System 2600 spectrometer on a PC/XT/AT type personal computer. J Microbiol Methods 15, 61-73.

Jukes, T. H. \& Cantor, C. R. (1969). Evolution of protein molecules. In Mammalian Protein Metabolism, vol. 3, pp. 21-132. Edited by H. N. Munro. New York: Academic Press.

Kim, S. B., Falconer, C., Williams, E. \& Goodfellow, M. (1998). Streptomyces thermocarboxydovorans sp. nov. and Streptomyces thermocarboxydus sp. nov., two moderately thermophilic carboxydotrophic species from soil. Int J Syst Bacteriol 48, 59-68.

Kim, S. B., Lonsdale, J., Seong, C. N. \& Goodfellow, M. (2003). Streptacidiphilus gen. nov., acidophilic actinomycetes with wall chemotype I and emendation of the family Streptomycetaceae $\left(\right.$ Waksman and Henrici $(1943)^{\mathrm{AL}}$ ) emend. Rainey et al. 1997. Antonie van Leeuwenhoek 83, 107-116.

Kudo, T., Itoh, T., Miyadoh, S., Shomura, T. \& Seino, A. (1993). Herbidospora gen. nov., a new genus of the family Streptosporangiaceae Goodfellow et al. 1990. Int J Syst Bacteriol 43, 319-328.

Kusakabe, H. \& Isono, K. (1988). Taxonomic studies on Kitasatosporia cystarginea sp. nov., which produces a new antifungal antibiotic cystargin. J Antibiot 41, 1758-1762.

Labeda, D. P. (1988). Kitasatosporia mediocidica sp. nov. Int J Syst Bacteriol 38, 287-290.

Lechevalier, M. P., Stern, A. E. \& Lechevalier, H. A. (1977). Chemotaxonomy of aerobic actinomycetes: phospholipid composition. Biochem Syst Ecol 5, 249-260.

Minnikin, D. E., Alshamaony, L. \& Goodfellow, M. (1975). Differentiation of Mycobacterium, Nocardia, and related taxa by thin-layer chromatographic analysis of whole-organism methanolysates. J Gen Microbiol 88, 200-204.

Minnikin, D. E., Collins, M. D. \& Goodfellow, M. (1979). Fatty acid and polar lipid composition in the classification of Cellulomonas, Oerskovia and related taxa. J Appl Bacteriol 47, 87-95.
Nakagaito, Y., Shimazu, A., Yokota, A. \& Hasegawa, T. (1992a). Proposal of Streptomyces atroaurantiacus sp. nov. and Streptomyces kifunensis sp. nov. and transferring Kitasatosporia cystarginea Kusakabe and Isono to the genus Streptomyces as Streptomyces cystargineus comb. nov. J Gen Appl Microbiol 38, 627-633.

Nakagaito, Y., Yokota, A. \& Hasegawa, T. (1992b). Three new species of the genus Streptomyces: Streptomyces cochleatus sp. nov., Streptomyces paracochleatus sp. nov., and Streptomyces azaticus sp. nov. J Gen Appl Microbiol 38, 105-120.

Ōmura, S., Iwai, Y., Takahashi, Y., Kojina, K., Otoguro, K. \& Oiwa, R. (1981). Type of diaminopimelic acid different in aerial and vegetative mycelia of setamycin-producing actinomycete KM-6054. $J$ Antibiot 34, 1633-1634.

Ōmura, S., Takahashi, Y., Iwai, Y. \& Tanaka, H. (1982). Kitasatosporia, a new genus of the order Actinomycetales. J Antibiot 35, 1013-1019.

Ōmura, S., Takahashi, Y., Iwai, Y. \& Tanaka, H. (1985). Revised nomenclature of Kitasatosporia setalba. Int J Syst Bacteriol 35, 221.

Prauser, H., Schütze, B. \& Martin, D. (editors) (1987). IMET National Collection of Microorganisms - Catalogue of Strains. Jena: ZIMET.

Rhuland, L. E., Work, E., Denman, R. F. \& Hoare, D. S. (1955). The behavior of the isomers of $\alpha, \varepsilon$-diaminopimelic acid on paper chromatograms. J Am Chem Soc 77, 4844-4846.

Saddler, G. S., Tavecchia, P., Lociuro, S., Zanol, M., Colombo, L. \& Selva, E. (1991). Analysis of madurose and other actinomycete whole cell sugars by gas chromatography. J Microbiol Methods 14, 185-191.

Saitou, N. \& Nei, M. (1987). The neighbor-joining method: a new method for reconstructing phylogenetic trees. Mol Biol Evol 4, 406-425.

Shirling, E. B. \& Gottlieb, D. (1966). Methods for characterization of Streptomyces species. Int J Syst Bacteriol 16, 313-340.

Tajima, K., Takahashi, Y., Seino, A., Iwai, Y. \& Ōmura, S. (2001). Description of two novel species of the genus Kitasatospora Ōmura et al. 1982, Kitasatospora cineracea sp. nov. and Kitasatospora niigatensis sp. nov. Int J Syst Evol Microbiol 51, 1765-1771.

Takahashi, Y., Iwai, Y. \& Ōmura, S. (1984). Two new species of the genus Kitasatosporia, Kitasatosporia phosalacinea sp. nov. and Kitasatosporia griseola sp. nov. J Gen Appl Microbiol 30, 377-387.

Uchida, K. \& Aida, K. (1984). An improved method for the glycolate test for simple identification of the acyl type of bacterial cell walls. J Gen Appl Microbiol 30, 131-134.

Waksman, S. A. \& Henrici, A. T. (1943). The nomenclature and classification of the actinomycetes. J Bacteriol 46, 337-341.

Wayne, L. G., Brenner, D. J., Colwell, R. R. \& 9 other authors (1987). Report of the ad hoc committee on reconciliation of approaches to bacterial systematics. Int J Syst Bacteriol 37, 463-464.

Yokota, A., Takeuchi, M., Sakane, T. \& Weiss, N. (1993). Proposal of six new species of the genus Aureobacterium and transfer of Flavobacterium esteraromaticum Omelianski to the genus Aureobacterium as Aureobacterium esteraromaticum comb. nov. Int J Syst Bacteriol 43, 555-564.

Zhang, Z., Wang, Y. \& Ruan, J. (1997). A proposal to revive the genus Kitasatospora (Ōmura, Takahashi, Iwai, and Tanaka 1982). Int J Syst Bacteriol 47, 1048-1054. 